\title{
Public Awareness of Lok Adalat Judiciary System in Rajasthan: An Empirical Approach to Law Reforms
}

\author{
Dr. Sonia Sharma ${ }^{1}$,Dr. Poonam Bawa ${ }^{2}$ \\ ${ }^{1}$ Post Doctoral Fellow (PDF) of ICSSR, New Delhi. Department of Political Science, \\ Jai Narain Vyas University, Jodhpur \\ ${ }^{2}$ Professor, Department of Political Science, Jai Narain Vyas University, Jodhpur \\ soniarbsharma@gmail.com,poonambawa@gmail.com
}

\begin{abstract}
The Lok Adalat originated from the failure of Indian legal system to provide fast, effective and affordable justice. It is one of the popular alternative dispute resolution systems in India for proving speedy and economical justice. The study examines the public awareness about the popular alternative system. The study is based on the primary data collected through structure questionnaire. The major conclusion drawn from the study is that there is a no significant relationship between gender, age group, income group, education level in regards awareness of Lok Adalats. Chi-Square statistical technique has been used for the purpose of testing of hypotheses. The results confirm that the awareness about the Lok Adalat is not affected by different gender, age group, income, occupation in the state of Rajasthan state.
\end{abstract}

Keywords: Lok Adalat, Legal Awareness, Justice, Judiciary

\section{INTRODUCTION}

In India there are nearly three crore pending cases in different Indian courts. The huge pendency of cases in court is major bottleneck in providing timely justice to victims. More than two third of these cases are pending in lower judiciary. Lok Adalat is one of the forwarding steps in proving rapid justices to the public. The public can only approach when they are aware about the Lok Adalats. The present research is attempt to measure public awareness about Lok Adalats in Rajasthan. Lok Adalat is potential utility to the existing legal system which has been overburdened with pending litigations (Chowbe and Dhonokar, 2012). According to the Article 14 of Indian constitution "the state shall not deny to any per son equality before law or the equal protection of law within the territory of India". Section (19) of the Legal Services Authority Act, 1987, gives responsibility to Central, State, and Taluk Legal Authority are power to organize Lok Adalats. The Lok Adalats are performing on equality and natural justice.

\section{Review of Literature}

A thorough review of literature available in the field of Lok Adalats has been made. Baxi (1976) suggested working efficiency and help in accelerating the speed of rendering justice to the needy people. He further stated that on the basis of nature of Lok Adalat, there are two types of functions which it must perform. One is manifest functions which may be specified i.e. conflict resolution, ombudsman, legal aid and services, legislative innovation, marital counseling, initiation of social changes etc. The second type of function is latent functions and dysfunctions. Subrahmanyam and Raju (2004) stated in their research that the Lok Adalat is beneficial to provide justice to the poor, backward and illiterate people. It provides them substantive, procedural laws. It is easily approachable system to resolve their disputes. Bisht (2004) focused on the behavior and act of the members during the Lok Adalats. The members of Lok Adalat must act as a neutral, ex per ience, intelligent, objective and benevolent. The members must make the efforts to negotiate the settlement and should not to be irritated and frustrated in case of no settlement. Their role is to be gentle per suasion to convince the parties. The members must give factual guidance, advice, mutual give and take. They have to proceed to dispose the case and arrive at the compromise or settlement between the parties.

Chowbe et al. (2011) threw deep insight into the Lok Adalat and its potential utility to the existing legal system. The study concluded that self-explanatory adaptations of Lok Adalats suit to the poor and needy people. Salkute's (2013) research is based on ADR mechanism. He suggested the need of 
effective mechanism to have expert determination in land encroachment certain cases which are to be referred before Lok Adalat. He suggested that before considering the cases in Lok Adalat, should securitized of cases by experts. By this way panel of Lok Adalat and parties get ample of opportunity to find out the way to settle the dispute. Sharma (2015) stated in her research paper that there is a positive and significant relationship between number of Lok Adalats and solved cases in the Rajasthan state. The research concluded that there is high degree of relationship between number of Lok Adalats and solved cases.

\section{Objectives of the Study}

The present study measures the public awareness of Lok Adalats in Rajasthan. The main objectives of the study are to determine whether there is any relationship between awareness about Lok Adalats with different gender, age group, income group, occupations and religion wise in Rajasthan and to provide recommendations for more popular of Lok Adalats in the state.

\section{Scope of the study}

The scope of Lok Adalats is being extended up to electronic system. In the stage E-Lokadalats has been introduced in parts of the country. The study is limited up to two major districts (Jodhpur and Jaipur) of Rajasthan State only. These two districts are important from legal point of view and expecting that the public of these districts are well aware about the lok adalats The study examines thorough primary data.

\section{Hypotheses}

For the purpose of the present research, the following hypotheses have been developed. It will help in verifying the research statement.

$\mathrm{H}_{01}$ : There is no significant difference between genders in terms of being aware of Lok Adalat.

$\mathrm{H}_{02}$ : There is no significant difference between age groups in terms of being aware of Lok Adalat.

$\mathrm{H}_{03}$ : There is no significant difference between the respondent of Jodhpur and Jaipur in terms of being aware of Lok Adalat.

$\mathrm{H}_{04}$ : There is no significant difference between the religion of Jodhpur and Jaipur in terms of being aware of Lok Adalat.

$\mathrm{H}_{05}$ : There is no significant difference between the Qualification of respondents and being aware of Lok Adalat.

$\mathrm{H}_{06}$ : There is no significant difference between the employment of respondents and being aware of Lok Adalat.

\section{Research Methodology}

'Lok Adalat in India is alternative dispute resolution systems. It is helping hand of the Indian courts, in solving pre-litigation and post litigated cases. For empirical study about public awareness of Lok Adalat primary data which has been collected through structured questionnaire. The analysis of data is based on Statistical Packages, namely, SPSS and Microsoft excel. The popular statistical technique: chi square has been used for testing of hypothesis. The dependent variables Gender, Age Group, Districts, Religion, Income, and Occupation is being considered for the study.

\section{RESPONSES FREQUENCY TABLES}

\section{Respondents Gender Wise:}

Table1. Gender Wise Respondents

\begin{tabular}{|l|l|l|}
\hline \multicolumn{2}{|l|}{ Respondents Gender Wise } \\
\hline & Frequency & Per cent \\
\hline Male & 100 & 83.3 \\
\hline Female & 20 & 16.7 \\
\hline Total & 120 & 100.0 \\
\hline
\end{tabular}

Table (1) shows the gender wise number of respondents. It is clear that out of 120 total respondents 100 (83.3 percent) are male respondents and 20 (16.7 per cent) are female. 


\section{Respondents Age Wise:}

Table1. Age Wise Respondents

\begin{tabular}{|l|c|c|}
\hline \multicolumn{2}{|c|}{ Age } & Per cent \\
\hline \multicolumn{1}{|c|}{ Age Criteria } & No. of Respondents & 4.2 \\
\hline Below 18 Years & 5 & 54.2 \\
\hline 18 to 35 Years & 65 & 29.2 \\
\hline 35 to 50 Years & 35 & 12.5 \\
\hline Above 50 Years & 15 & 100.0 \\
\hline Total & 120 & \\
\hline
\end{tabular}

Table (2) given above mentions the frequency of respondents age. It shows that 5 (4.2 per cent) are below 18 years, most of the respondents are between 18 to 35 that is 65 (54.2 per cent), Age 25 to 50 clear that out of 120 total respondents 100 (83.3 per cent) are male respondents and 20 (16.7 per cent) are female.

\section{Respondents Marital Status Wise:}

Table3. Marital Status Wise Respondents

\begin{tabular}{|l|c|c|}
\hline \multicolumn{2}{|c|}{ Marital Status } \\
\hline Married & Frequency & Per cent \\
\hline Unmarried & 88 & 73.3 \\
\hline Total & 32 & 26.7 \\
\hline
\end{tabular}

As per the table (3) it is evident that the 73.3 percent are married respondents and 32 per cent are unmarried respondents.

\section{Respondents District Wise (Jodhpur and Jaipur) :}

Table4. District Wise (Jodhpur and Jaipur) Wise Respondents

\begin{tabular}{|l|c|c|}
\hline \multicolumn{2}{|c|}{ District of Rajasthan } \\
\hline & Frequency & Per cent \\
\hline Jodhpur & 71 & 59.2 \\
\hline Jaipur & 49 & 40.8 \\
\hline Total & 120 & 100.0 \\
\hline
\end{tabular}

As per the table (4) it is clear that the 71 percent respondents are from Jodhpur district and 49 percent respondents are from Jaipur.

\section{Respondents Religion Wise:}

Table5. Religion Wise Respondents

\begin{tabular}{|l|c|c|}
\hline \multicolumn{2}{|c|}{ Religion Wise } \\
\hline Religions & Frequency & Per cent \\
\hline Hindu & 105 & 87.5 \\
\hline Muslim & 10 & 8.3 \\
\hline Christian & 1 & .8 \\
\hline Sikh & 1 & .8 \\
\hline Jain & 3 & 2.5 \\
\hline Total & 120 & 100.0 \\
\hline
\end{tabular}

Table (5) depicts the frequency of respondents on the basis of their religion. The table shows that 105 (87.5 per cent) are Hindu, 10 (8.3 per cent) are Muslims, and Christians are 0.8 per cent, Sikh also .8 per cent and Jain are 2.5 per cent of total respondents.

\section{Respondents Education Qualifications Wise:}

Table6. Education Qualification Wise Respondents

\begin{tabular}{|l|c|c|}
\hline \multicolumn{2}{|c|}{ Educational Qualification } \\
\hline & Frequency & Per cent \\
\hline Ph.D. & 4 & 3.3 \\
\hline Post Graduation & 43 & 35.8 \\
\hline Graduation or Diploma & 39 & 32.5 \\
\hline
\end{tabular}


Public Awareness of Lok Adalat Judiciary System in Rajasthan: an Empirical Approach to Law Reforms

\begin{tabular}{|l|c|c|}
\hline \hline Professional Degree & 16 & 13.3 \\
\hline Higher Secondary & 13 & 10.8 \\
\hline Primary Education or below & 5 & 4.2 \\
\hline Total & 120 & 100.0 \\
\hline
\end{tabular}

Qualification is always important matter education and justice point of view to understanding and implementing the results. Thus, it is important to identify the qualification of the respondents. Table (6) gives the categories of respondents according to academic and professional qualifications. Out of the respondents are Post Graduates 43(35.8 percent), graduated are 39 (32.5 percent), Professional degree holders are 13.3 percent, and $\mathrm{Ph}$. D. holders are 3.3 percent.

\section{Respondents: Occupation Wise}

Table7. Occupation wise Respondents

\begin{tabular}{|l|c|c|}
\hline \multicolumn{3}{|c|}{ Occupation Wise } \\
\hline Government Job & Frequency & Per cent \\
\hline Private Job & 28 & 23.3 \\
\hline Business or Profession & 31 & 25.8 \\
\hline Others & 44 & 36.7 \\
\hline Total & 17 & 14.2 \\
\hline
\end{tabular}

Occupation wise respondents are shown in table (7). The highest number of respondents are engaged in business or professions 44 (36.7 percent), respondents are in government service 28(23.3 percent), engaged in private service are 31(25.8 per cent) and others are 17(14.2 per cent) out of 120(100 per cent) of the respondents.

\section{Respondents: Income Group Wise}

Table8. Monthly Income Group Wise Respondents

\begin{tabular}{|l|l|l|}
\hline Monthly Income & Frequency & per cent \\
\hline & 80 & 66.7 \\
\hline Below 25000 INR & 24 & 20.0 \\
\hline 25000 to 50000 INR & 11 & 9.2 \\
\hline 50000 to 75000 INR & 5 & 4.2 \\
\hline 75000 INR and Above & 120 & 100.0 \\
\hline Total & The & Ras \\
\hline
\end{tabular}

In table (8) the respondents have been shown on the basis of their income group. The highest number of respondents are below 25000 per month income 80(66.7 percent), the respondents income is between 25000 to 50000 are 24(20 per cent), 50000 to 75000 are $11(9.2$ per cent) and only 5(4.2 per cent) respondents are above 75000 INR monthly income group.

\section{Respondents: Legal Professionals:}

Table9. Respondents in Legal Profession

\begin{tabular}{|l|l|l|}
\hline \multicolumn{2}{|l|}{ Respondents in Legal Profession } & Frequency \\
\hline Legal Professional & 40 & per cent \\
\hline Not Legal Professional & 80 & 33.3 \\
\hline Total & 120 & 66.7 \\
\hline
\end{tabular}

Table (9) reveals that 40 (33.3 per cent) respondents are directly or indirectly related to legal professional it includes advocates, law graduates, justices, legal consultants etc. Out of 120, 80(66.7) are not legal professional respondents.

\section{MEASURING GENERAL AWARNESS ABOUT LOK ADALATS}

For the purpose of measuring general awareness about Lok Adalats, following research questions have been developed:

Research Question: 1 Do you know about Lok Adalat?

Research Question: 2 Does Lok Adalat is economical system in judiciary?

Research Question: 3 Does Award of Lok Adalat satisfy both the parties?

Research Question: 4 Does Lok Adalat reduce the pendency of Cases? 
Public Awareness of Lok Adalat Judiciary System in Rajasthan: an Empirical Approach to Law Reforms

District-wise Analysis of responses:

Table10.

\begin{tabular}{|c|c|c|c|}
\hline \multicolumn{4}{|c|}{ Do you know about Lok Adalats ? } \\
\hline Districts & Yes & No & Total \\
\hline \multirow{2}{*}{ Jodhpur } & 64 & 7 & $(100.0)$ \\
\cline { 2 - 4 } & $(90.1)$ & $(9.9)$ & 49 \\
\hline \multirow{2}{*}{ Jaipur } & 47 & 2 & $(100.0)$ \\
\cline { 2 - 4 } & $(95.9)$ & $(4.1)$ & $(100.0)$ \\
\hline \multirow{2}{*}{ Total } & 111 & 9 & $(7.5)$ \\
\end{tabular}

Source: Compiled and computed from the Questionnaire

Note: Figures within brackets show the percentage to total.

Tables (10) reveals that response rate in selected districts. It shows that 90 percent respondents in Jodhpur and 95.9 per cent respondents are aware about in Jaipur districts.

Table11.

\begin{tabular}{|l|c|c|c|}
\hline \multicolumn{4}{|c|}{ Does Lok Adalat economical system of judiciary? } \\
\hline Districts & Yes & No & Total \\
\hline \multirow{3}{*}{ Jodhpur } & 63 & 8 & 71 \\
\cline { 2 - 4 } & $(88.7)$ & $(11.3)$ & 49 \\
\hline \multirow{2}{*}{ Jaipur } & 43 & 6 & $(100.0)$ \\
\cline { 2 - 4 } & $(87.8)$ & $(12.2)$ & 120 \\
\cline { 2 - 4 } & 106 & 14 & $(100.0)$ \\
\hline
\end{tabular}

Source: Compiled and computed from the Questionnaire

Note: Figures within brackets show the percentage to total.

Tables (11) shows the response about economical feature of lok adalat. 88.7\% from Jodhpur and $87.8 \%$ respondents are agreed from Jaipur agreed Lok adalats are economical system of Judiciary.

Table12.

\begin{tabular}{|l|l|l|l|}
\hline Does award of Lok Adalat satisfies both the parties? \\
\hline Districts & Yes & No & Total \\
\hline \multirow{3}{*}{ Jodhpur } & 66 & 5 & 71 \\
\cline { 2 - 4 } & $(93.0)$ & $(7.0)$ & $(100.0)$ \\
\hline \multirow{2}{*}{ Jaipur } & 45 & 4 & 49 \\
\cline { 2 - 4 } & $(91.8)$ & $(8.2)$ & $(100.0)$ \\
\hline \multirow{2}{*}{ Total } & 111 & 9 & 120 \\
\cline { 2 - 4 } & $(92.5)$ & $(7.5)$ & $(100.0)$ \\
\hline
\end{tabular}

Source: Compiled and computed from the Questionnaire

Note: Figures within brackets show the percentage to total.

Tables (12) clarify the respondents' opinion about the unique feature of Lok Adalat that the Lok Adalat system satisfies both the parties by given award. The 93 per cent in Jodhpur and 91.8 per cent respondents are agreed in Jaipur are agreed on it.

Table13.

\begin{tabular}{|c|c|c|c|}
\hline \multicolumn{4}{|c|}{ Does Lok Adalat reduces pending cases of courts? } \\
\hline Districts & Yes & No & Total \\
\hline \multirow{2}{*}{ Jodhpur } & 57 & 14 & 71 \\
\cline { 2 - 4 } & $(80.3)$ & $(19.7)$ & $(100.0)$ \\
\hline \multirow{2}{*}{ Jaipur } & 39 & 10 & $(100.0)$ \\
\cline { 2 - 4 } & $(79.6)$ & $(20.4)$ & 120 \\
\hline Total & 96 & 24 & $(100.0)$ \\
\cline { 2 - 4 } & $(80.0)$ & $(20.0)$ & cent \\
\cline { 2 - 4 }
\end{tabular}

Tables 13 shows that the 80.3 per cent of the respondents in Jodhpur and 79.6 per cent respondents in Jaipur are that the lok adalats reduces pending cases of Indian courses. 
Public Awareness of Lok Adalat Judiciary System in Rajasthan: an Empirical Approach to Law Reforms

Table14.

\begin{tabular}{|l|c|c|c|}
\hline \multicolumn{3}{|c|}{ Does Lok Adalat not help in reducing pending cases? } \\
\hline Districts & Yes & No & Total \\
\hline \multirow{3}{*}{ Jodhpur } & 31 & 40 & $(100.0)$ \\
\cline { 2 - 4 } & $(43.7)$ & $(56.3)$ & 49 \\
\cline { 2 - 4 } & 21 & 28 & $(100.0)$ \\
\hline \multirow{2}{*}{ Total } & $(42.9)$ & $(57.1)$ & $(100.0)$ \\
\cline { 2 - 4 } & 52 & 68 & $(56.7)$ \\
\hline
\end{tabular}

Source: Compiled and computed from the Questionnaire

Note: Figures within brackets show the percentage to total.

Tables 14 shows the cross question response of the respondents. This research question verifying the responses of other questions. The table shows that 43.7 per cent of the respondents in Jodhpur and 42.9 per cent respondents in Jaipur are not fully agree that the lok adalats are reducing pending cases of Indian courses.

\section{Testing of Hypotheses:}

$\mathrm{H}_{01}$ : There is no significant difference between genders in terms of being aware of LOK ADALAT.

Table15.

\begin{tabular}{|l|c|c|c|c|c|}
\hline \multicolumn{7}{|c|}{ Chi-Square Tests } \\
\hline Pearson Chi-Square & Value & df & Asymp. Sig. (2-sided) & Exact Sig. (2-sided) & Exact Sig. (1-ided) \\
\hline Continuity Correction & .343 & 1 & .253 & & \\
\hline Likelihood Ratio & 1.061 & 1 & .558 & & \\
\hline Fisher's Exact Test & & & .303 & & .252 \\
\hline $\begin{array}{l}\text { Linear-by-Linear } \\
\text { Association }\end{array}$ & 1.296 & 1 & .255 & & \\
\hline N of Valid Cases & & & & & \\
\hline
\end{tabular}

The result given in the table (15) show the value of chi square $(\chi 2)$ for one degree of freedom at 5 per cent level of significance is 3.84 . The calculated value (.253) of $\chi^{2}$ is less than the table value which means that the calculated value. Therefore, the null hypothesis is accepted. It is statistically proved that there is no significant difference between the gender (male and female) and awareness about the lok adalats. The results show that male and females both are positively aware about lok adalat system.

$\mathrm{H}_{02}$ : $\quad$ There is no significant difference between age groups in terms of being aware of LOK ADALAT.

Table16.

\begin{tabular}{|l|c|c|c|}
\hline \multicolumn{4}{|c|}{ Chi-Square Tests } \\
\hline Pearson Chi-Square & Value & df & Asymp. Sig. (2-sided) \\
\hline Likelihood Ratio & $.482^{\mathrm{a}}$ & 3 & .923 \\
\hline Linear-by-Linear Association & .854 & 3 & .836 \\
\hline N of Valid Cases & .051 & 1 & .821 \\
\hline
\end{tabular}

Table (16) shows the value of Chi-square $\left(\chi^{2}\right)$ for three degree of freedom at 5 per cent level of significance is 7.815 . The calculated value (.482) of $\chi^{2}$ is less than the table value which means that the calculated value. Therefore, the null hypothesis is accepted. It is statistically proved that there is no significant difference between the age group and awareness about the lok adalats. The results show that all age group are equally aware about lok adalat system.

$\mathrm{H}_{03}$ : $\quad$ There is no significant difference between the respondent of Jodhpur and Jaipur in terms of being aware of LOK ADALAT.

Table17.

\begin{tabular}{|l|c|c|c|c|c|}
\hline \multicolumn{7}{|c|}{ Chi-Square Tests } \\
\hline & Value & df & Asymp. Sig. (2-sided) & Exact Sig. (2-sided) & Exact Sig. (1-sided) \\
\hline Pearson Chi-Square & $1.395^{\mathrm{a}}$ & 1 & .238 & & \\
\hline Continuity Correction $^{\mathrm{b}}$ & .686 & 1 & .407 & & \\
\hline
\end{tabular}


Public Awareness of Lok Adalat Judiciary System in Rajasthan: an Empirical Approach to Law Reforms

\begin{tabular}{|c|c|c|c|c|c|}
\hline Likelihood Ratio & 1.500 & 1 & .221 & & \\
\hline Fisher's Exact Test & & & & .307 & .207 \\
\hline $\begin{array}{l}\text { Linear-by-Linear } \\
\text { Association }\end{array}$ & 1.383 & 1 & .240 & & \\
\hline $\mathrm{N}$ of Valid Cases ${ }^{b}$ & 120 & & & & \\
\hline
\end{tabular}

Table (17) shows the value of Chi-square $(\chi 2)$ for one degree of freedom at 5 per cent level of significance is 3.84. The calculated value (.238) of $\chi 2$ is less than the table value which means that the calculated value. Therefore, the null hypothesis is accepted. It is statistically proved that there is no significant difference between the districts (Jodhpur and Jaipur) and awareness in public about the lok adalats. The results shows that both districts people are equally aware about lok adalat system.

$\mathrm{H}_{04}$ : There is no significant difference between the religion of Jodhpur and Jaipur in terms of being aware of LOK ADALAT.

Table18.

\begin{tabular}{|l|c|c|c|}
\hline \multicolumn{3}{|c|}{ Chi-Square Tests } \\
\hline & Value & df & Asymp. Sig. (2-sided) \\
\hline Pearson Chi-Square & $.451^{\text {a }}$ & 4 & .978 \\
\hline Likelihood Ratio & .823 & 4 & .935 \\
\hline Linear-by-Linear Association & .264 & 1 & .607 \\
\hline N of Valid Cases & 120 & & \\
\hline
\end{tabular}

Table (18) exhibits the value of Chi-square $(\chi 2)$ for four degree of freedom at 5 per cent level of significance is 11.345 . The calculated value (.238) of $\chi^{2}$ is less than the table value which means that the calculated value. Therefore, the null hypothesis is accepted. It is statistically proved that there is no significant difference between the districts (Jodhpur and Jaipur) and awareness in public about the lok adalats. The results shows that both districts people are equally aware about lok adalat system.

Descriptive Statistics:

Table19.

\begin{tabular}{|l|l|l|l|}
\hline Descriptive Statistics & $\mathrm{N}$ & Mean & Std. Deviation \\
\hline Are you aware about Lok Adalat ? & 120 & 1.08 & .264 \\
\hline Does Lok Adalat easy and economical system of judiciary? & 120 & 1.12 & .322 \\
\hline Does Lok Adalat satisfy both the parties? & 120 & 1.08 & .264 \\
\hline Does Lok Adalat help in reducing pending cases of courts? & 120 & 1.20 & .402 \\
\hline
\end{tabular}

The result of table 19 shows descriptive statistics about general awareness about lok adalat in both the selected districts.

\section{MAJOR FINDINGS}

1. It is observed that in Rajasthan the most of people are well aware about the lok adalats which shows the popularity of Lok Adalats. The data also reflects that the average 92.5 per cent in Jodhpur and 95.9 per cent in Jaipur people are aware of the Lok Adalats in Rajasthan.

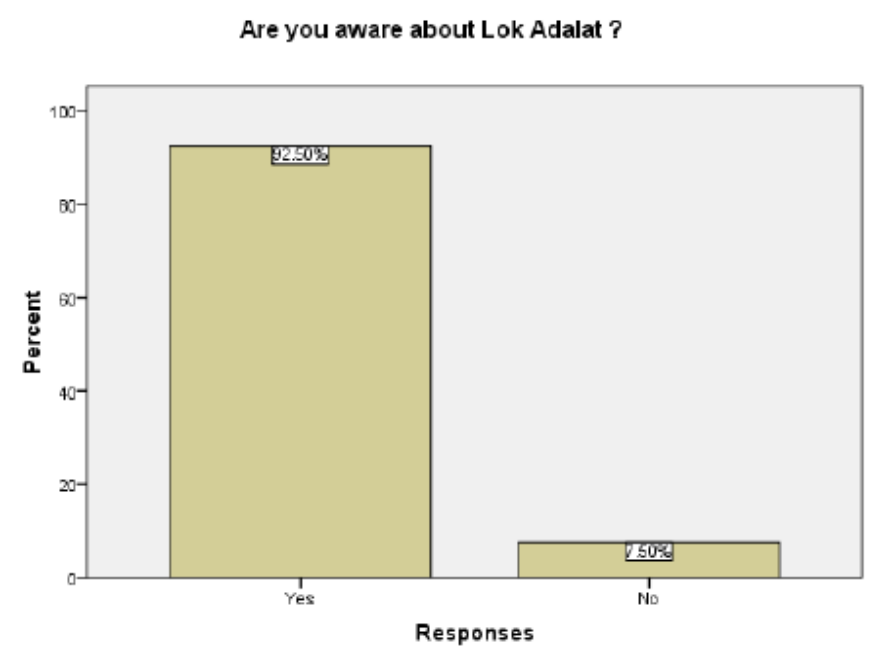


2. Most of public of Rajasthan agreed that the Lok Adalat system is not only easily also but to approach and economical system in judiciary. The. 88.7 per cent in Jodhpur and 87.3 per cent in Jaipur people are agreed on it.

Does Lok Adalat is easy and economical system in judiciary?

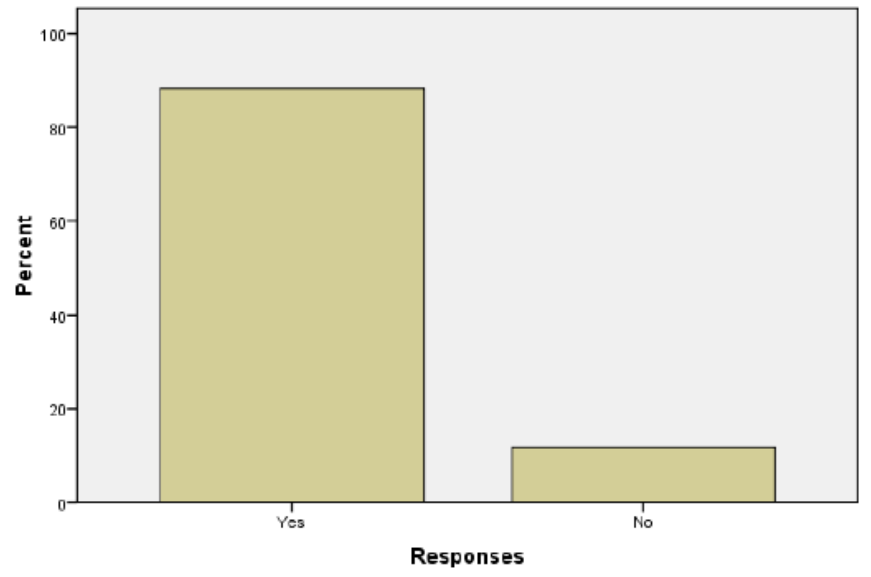

3. The public of Rajasthan agreed that the award of lok adalat satisfy both the parties. There are. 93 per cent in Jodhpur and 91.8 per cent in Jaipur people are agreed on it.

Does Lok Adalat satisfies both the parties?

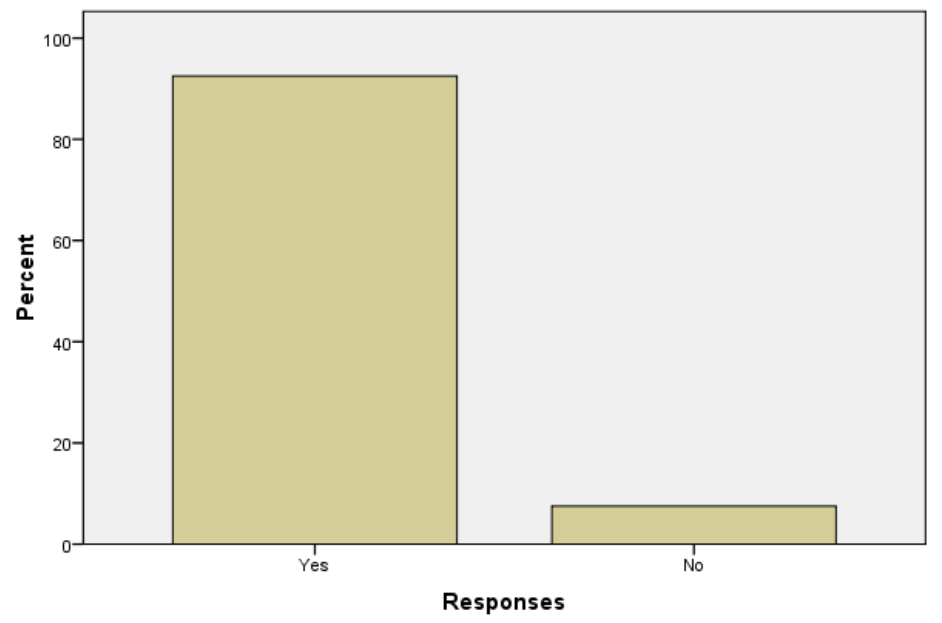

4. The public of Rajasthan agreed that the Lok Adalat system is reducing pendency of cases of different Indian courts. 80.3 per cent in Jodhpur and 79.6 per cent in Jaipur people are agreed on it.

Does Lok Adalat reduces pending cases of courts?

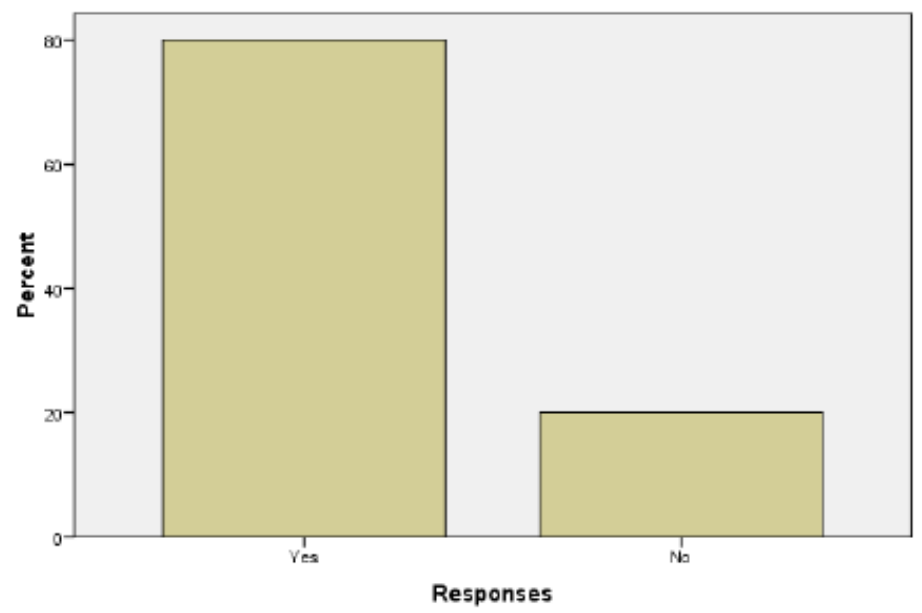




\section{Concluding Observations}

The present study is to evaluate the general awareness of Lok Adalats in Rajasthan state. It is found that there is no significant relationship between gender, age group, monthly income and occupation of public and general awareness of Lok Adalats in Rajasthan State. The result shows the Lok Adalat is popular and successful in Rajasthan. However at the same time the results also reveled that judiciary and government agencies are efficiently working towards publicity of lok adulates. The concern parties also get benefits from the lok adulates It is thus concluded that overall general awareness of Lok Adalats in Rajasthan state are functioning effectively and towards positive direction in judiciary system.

\section{ACKNOWLEDGEMENT}

This paper is part of the post doctoral research project funded by the Indian Council of Social Science Research (ICSSR), New Delhi, INDIA. The authors are grateful to the institution for financial support.

\section{REFERENCES}

[1] Baxi Upender (1976) From Takrar to Karar: The Lok Adalat, Rangpur, pp, 53-64.

[2] Bisht J.S. (2004), "Lok Adalat: A Mechanism of Alternate Dispute Resolution," 31 Indian Bar Review, 165 at p179.

[3] Criminal Survey: Rajasthan 2013, State Crime Report Bureau, Rajasthan Jaipur.

[4] Chowbe, Vijaykumar Shrikrushna and Dhanokar, Priya (2011), Lok Adalat - A Strategic Forum for Speedy and Equitable Justice. Available at SSRN: http://ssrn.com/abstract=1766237 or http://dx.doi.org/10.2139/ssrn.1766237

[5] Discussion Paper (May, 2013), Judiciary- A Crumbling Pillar of Indian Democracy? speeding up delivery of justice in India. (http://www.cuts-ccier.org/pdf/Judiciary_a_crumbling_pillar_of_ Indian_democracy-Speeding_up_delivery_of_justice_in_India.pdf)

[6] Raju, Dr. K. D. (2007), Alternate Dispute Resolution System: A Prudent Mechanism of Speedy Redress in India (December 15, 2007). Available at SSRN: http://ssrn.com/abstract=1080602 or http://dx.doi.org/10.2139/ssrn.1080602

[7] Khanwilkar A. M. (2005); "Need of Revitalise ADR Mechanism," 6 Nyaya Deep, p.60.

[8] Subrahmanyam A. and Raju A.S. (2004), "Distributive Justice: Indian per spective," AIR 2004 Jour 16 p.20.

[9] Salkute, Sanjay Rambhau (2013), Need of Ex per t Determination before A.D.R.(Lok Adalat) in Land Encroachment Civil Suits (Suggested Method), International Journal of Scientific and Research Publications, Volume 3, Issue 1, November 2013, ISSN 2250-3153.

[10] Sharma Sonia (2015), EVALUATION OF LOK ADALATS IN RAJASTHAN: AN EMPIRICAL STUDY, Global Journal of Politics and Law Research, Vol.3, No.2, pp.69-78

\section{Electronic Resources}

[11] www.legalserviceindia.com

[12] www.indiankanoon.org

[13] www.shodhganga.inflibnet.ac.in

[14] www.academia.edu

[15] www.dlsa.nic.in

[16] www.kaanoon.com 


\section{AUTHORS' BIOGRAPHY}

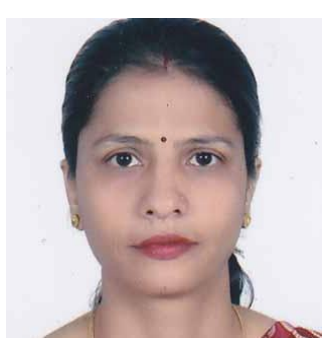

Dr. Sonia Sharma, is Post Doctoral Fellow of Indian Council of Social Science Research, New Delhi, and also associated with Jai Narain Vyas University, Jodhpur. She obtained her Ph.D. in Political Science from University of Rajasthan, Jaipur and her teaching experience is more than 14 years. She authored one book on Lok Adalat and published five research papers in national and international journals. Besides, she has attended a number of national and international seminars and workshops in India and abroad. She is also member of professional body of political science in India.

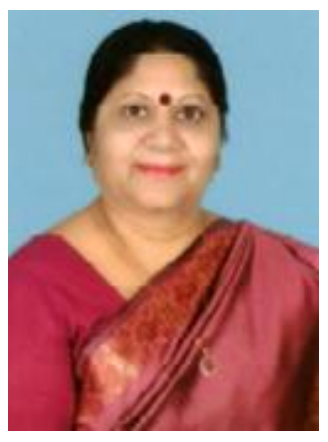

Dr. Poonam Bawa, is Professor in the Department of Political Science, J.N.V. University, Jodhpur. She is M.A (gold medalist), PhD in Political Science, and P.G. Diploma in Gandhian Studies. University teaching experience is of thirty four yrs and author of two books : "Hindu Revivalism, Its ideological roots of Nationalism" and "Power Politics and Women in India" She has published a number of research papers in national and international journals and was the Chief Editor of Indian Journal of Political Studies(refereed journal), published by the department of Political Science. A versatile personality capable of rendering service to the society multi dimensionally, she is the founding Director of U.G.C. Sponsored Centre for Women's Studies in the University (2005-11) and worked for gender equality and woman empowerment in Western Rajasthan. She is chief warden of Girls Hostels and Chairperson "Committee on Sexual Harassment of Women at Workplace, Prevention Prohibition and Redressal". 